\title{
The Pattern of Life of Spoken Communities: Ethnographic Studies of Communication on Student's Social Life
}

\author{
Pahrul Idham Kaliky $^{1 *}$, Hanafi Bilmona ${ }^{2}$, Aisa Abas ${ }^{3}$ \\ ${ }^{1,2,3}$ Universitas Pattimura Ambon, Indonesia \\ *Correspondence to: Pahrul Idham Kaliky, Universitas Pattimura Ambon, Indonesia, E-mail: pahrul.kaliky@fisip.unpatti.ac.id
}

\begin{abstract}
Students are a social community where the basic views and primary cells grow from the basic views and scientific disciplines in the academic world. Students have their own culture of social life in their main activities, which are seen as very functioning as the main pillar in the development of human resources and as a determinant of a nation's quality level. The research aims to determine the social interaction behavior of students in several faculties at Pattimura University. With a background of good student social interaction behavior in several faculties, a harmonious social relationship will be built between fellow students in the Pattimura University campus environment. This research is qualitative research, designed based on a constructive paradigm in which every speech and action community is not only interpreted from a particular perspective but needs to be understood holistically based on the cultural approach and characteristics of each region. This research is based on an interpretive paradigm that views the world and objects of human life from their experience and subjectivity and has different views from the positivistic paradigm. When the positivistic paradigm uses a basic premise with a short phrase, knowledge is un-problematic, the interpretive paradigm sees the opposite.
\end{abstract}

Keywords:

Students, Communication, Multi-cultural, Ethnography.

Article Received: 18 October 2020, Revised: 3 November 2020, Accepted: 24 December 2020

\section{Introduction}

History proves the development of a nation cannot be separated from the participation of students in it; students are a social community where the basic views and primary cells of their activities grow from the basis of opinions and scientific disciplines in the academic world they live in (Wild \& Ebbers, 2002; Axelson \& Flick, 2010). Having a myriad of knowledge and experiences in education will undoubtedly be very beneficial for individuals and groups internally in the campus world. The tangible form can be seen from how they apply it in community life outside the campus as a form of social life for the community, nation, and state (Morey, 2000; Tonso, 2006). The characteristics and character of each under the umbrella of higher education which is known as a campus, of course, students have a culture of their own life in their primary activities which are seen as functioning as the central pillar in the development of human resources and as a determinant of the quality level of a nation (Gonzales, 2002; Lee, 2004; Shen \&
Tian, 2012). Departing from the culture of sophistication and academics with various scientific disciplines, the role of students has been confirmed to be very significant in determining the direction of the nation's life, including as a determinant of the movement of government policies in state life (Cahyono, 2014; Istichomaharani \& Habibah, 2016).

The role of students as found in various countries that have progressed in the field of technology, such as Japan as one of the countries with established technology, has now strengthened its education system leading to the approach of knowledge and awareness of students, especially to understanding culture as a means of bonding relationships. Social among them. Several colleges/universities in Japan have set up their learning curricula referring to cross-cultural understanding, which is applied in the form of communication in student life (Brown, 2009; Kudo \& Simkin, 2003). It is genuinely realized that the level of understanding across cultures plays a significant role in globalization's needs in 
today's world (Ahmed, 2013; Rose-redwood, 2010).

The fundamental question posed by Jeny Han in the DIS Study Abroad in Scandinavia is that how we can communicate and collaborate with people at the age level globally to be able to increase the space for economic, technological, and cultural movement towards closer integration without understanding what happens when communicants in different worlds and different communication styles are simultaneously forced to live together with one another (DIS, 2016).

Referring to experts' considerations and the reality of the formation of student life as part of the academic community at a university with different cultural backgrounds, it can be viewed from several aspects to determine the focus and reason for this research (Turmudi, 2019). Campus or university life, in general, has its characteristics ranging from curriculum settings related to the management of education administration, the use of academic terms, the character of social life among students internally, to activities outside the campus environment, of course, all of them have a sense of value with their nuances. A generalized label is interpreted as meaning "student" (Munthe \& Chandra, 2011; Sanit, 2018). Regardless of the generalization of the name tags they carry, the formation of individual student personalities, consciously or unconsciously, has experienced a tremendous psychological impact or shock. This is, of course, because individual students will begin to grow in a multiculturalism structure that is very extraordinary (Kelly, 2015; Permatasari \& Bariyah, 2016). Because each student comes from a background in cultural life ranging from the eastern part to the western part of Indonesia, even to individual students who come from outside the territory of Indonesia (International students). This is the main point deemed necessary to be appropriately considered to not cause social pathology or social disease by Kartini Kartono in Burlian (2016). It is said that disease is related to the nature of human existence in society.

Departing from differences in the cultural backgrounds of existing students, Pattimura
University or abbreviated as Unpatti, which on this occasion was used as a research location, is an educational institution with its status as the largest state university (PTN) in Maluku Province, which is domiciled in Ambon City, it accommodates several students and female students (from the gender category) with different cultural backgrounds. The differences in students' experiences can be broadly classified into; students who come from within the geographic Maluku region, students who come from outside the geographical Maluku region, and students who are known as International students.

Apart from students who are categorized as international students, students outside the geographic area of Maluku are again classified as students who come from the closest locations, around the Maluku region, for example, such as; Ternate, NTT, and Papua; and those who come from outside Maluku such as areas around Sulawesi, Kalimantan, Java, Sumatra and the other regions outside Maluku. This category or classification of students is solely based on a general view of cultural differences. It is more specifically related to the interaction between people on campus and outside campus life related to academic activities and social activities in their daily lives.

Pattimura University students in the geographic first category approach, specifically from 11 (eleven) Regencies / Cities spread over the Maluku Province. Those who are still in an area but from each of these regions are still within the Malukan frame boundary with a cultural background that is still very thick and yet very different. This is because the province of Maluku itself geographically in Ralahalu, (2008), consists of 12 (twelve) island clusters, including: Island Cluster I; Includes Buru Island and Ambalau Island, Island Cluster II; Includes West Seram Island, namely Buano Island, Kelang Island, Babi Island, and Manipa Island, Island Cluster III; North Seram Administrative Region, Island Cluster IV; Eastern Seram, namely Parang Island, Geser, Talang Seram Laut, Gorong Islands (Gorong, Panjang and Manovoka Islands), 
Watubela Islands (Watubela, Kesui and Rumoi Islands), Cluster V Island; Southern Seram Island (Amahi, Teon Nila Serua (TNS) and Tehoru), Cluster Island VI; Banda Island (Suanggi Island, Gunung Api, Neira, Run Ai and Banda Besar), Teon Island, Nila and Serua, Island Cluster VII; Pulau-Pualu Lease (Ambon Saparua, Nusalaut, Haruku and Molana), Turtle Islands and Lucipara, Island Cluster VIII; Small islands which are now included in the Southeast Maluku Administrative region, Cluster IX; Islands that are included in the administrative area of Aru Islands, Island Cluster X; Tanimbar, Larat, Selaru, Sera, Wuliaru and Molu Islands, Island Cluster XI; Babar Islands and Sermata Island, Island Cluster XII; Damar, Romang, Leti, Moa, Lakor, Kisar, Wetar, Liran and Reong Islands.

This regional grouping in clusters is considered to have a unique cultural value that needs to be deepened in the study using the ethnographic communication approach. Departing from the islands' group, there are 2 (two) things that need to be understood from a theoretical perspective, from a student sociology point of view, and an ethnographic standpoint of student communication. Looking at the characteristics of the social background of students who come from islands from the archipelago community's sociological perspective, it must be admitted that building good social student behavior as part of an island society is not something that is considered easy. This is because students who come from archipelagic areas previously lived on small islands with their social characteristics in various ways of life and ways of interacting socially by looking; multi sub-ethnic, multi-language, multicharacter, multi tradition, and multi-culture holistically. This condition certainly requires an approach that philosophically refers to an acknowledgment of the ontological bases of students based on an individual system so that from the existing cultural differences it can be led to an awareness of national insights towards the foundation and philosophical and ideological views of the nation, unity in diversity leading to the creation of generations. - Pancasila generation in one unitary frame of the Republic of Indonesia, which is healthy and intact.

Based on the views above, the study entitled Speech Community Life Pattern: Ethnographic Study of Communication in Student Social Life was appointed with the aim and hope of finding a design or model that is closer to the point that answers the challenges in multi-cultural life students as a continuation of the nation's generation, and their big hope is the younger generation, students in each period of campus life will be processed in such a way as to approach the intended goal, to produce mentally capable outputs and able to integrate their lives with others by understanding the essence of a difference, at least as God's creatures who have outlined them with all His plans. This is related to Koentjaraningrat's view, in Kuswarno (2008), where culture speaks in communication behavior which is nothing but related to how the language can be used by people of different cultures from the sociological and ethnographic aspects of communication by upholding the essence of language as a unifying social tool.

This study aims to obtain a new educational design model by applying a new curriculum at the Pattimura University level, reflecting the university's vision and mission with the LAUTISLAND character. This research aims to obtain a form of academic, social life with specific characteristics to design an appropriate pattern or model based on the existing vision and mission. Specifically, this study aims to find students' social interaction behavior in several faculties at Pattimura University. Knowing the impact of student social interaction behavior on many faculties and establishing harmonious social relationships among fellow students and female students in the Pattimura University campus environment.

\section{Methods}

Quantitative research with a case-control study This research is based on an interpretive paradigm that views the world and objects of human life from their experience and subjectivity and has different views from the positivistic 
paradigm. In other words, when the positive paradigm uses a basic premise with a short phrase, knowledge is un-problematic; the interpretive paradigm sees the opposite. On this basis, this study uses a qualitative research design, a way of investigating and understanding an individual or group toward a particular social phenomenon (Creswell, 2011).

Examining students' quantity, especially Pattimura University students, is not an easy quantity to be used as a "subject" of research that meets elements of research validity. Therefore, a systematic approach that meets research principles needs to be determined precisely from the perspective of research solidity according to Stake (1985) and Freebody (2003) in Emilia (2005), which considers "scale" (small) and the 'single case.' mainly focus on an instance of educational experience or practice". The scale in question is a portion of students from all students in 9 (nine) faculties at Pattimura University. They were selected using a purposive approach, which is an appropriate categorization point of view. This study will also use a snowball sample approach for data accuracy in determining students' cultural characteristics. As this research emphasizes communication, then this purposive approach will be applied to get research subjects from a language cultural background based on the classification of different families.

\section{Results}

After analyzing the data from in-depth interviews with students considered representative, the data were then grounded between the categories of data representation from one another (between students with different cultural and ethnic backgrounds). From the results of dropping the data, it is concluded that the results are related to the form of communication behavior in student social life; there are no differences in behavior that appear from a linguistic point of view based on differences in language family categories. On the other hand, what was found was the communication behavior in a regional approach from the point of view of the geographical location of a particular area in general. This difference can be generally divided, namely those who are within the Maluku Province but outside the language culture around Ambon City and the Central Maluku Regency area (1), those who come from within the Maluku Province but in the Southeastern Maluku region, Maluku Southwest and its surroundings, North Maluku, areas around Papua Province and NTT Province; (2) on a different side, the Makassar region, around Sumatra and Kalimantan (3) at a level that is considered to be the same as the average, (4) the Buton region and the Java area are each independent, related to this social behavior.

The study results also found that there were impacts as a response to reality for several different categories, where these impacts broadly covered or were included in two different disciplinary areas. The two types of disciplinary areas are in the psychological realm, while the other is in the domain of communication itself. The impact related to the psychological problem in question, from the results of in-depth interviews with participants, has received several things as a result of which there is tremendous psychological pressure, especially the communicant who feels embarrassed and does not dare to build communication with other people because he feels ashamed and feels pressured by the inner burdens. Heavy can create a gap to think that the other person is someone else or a stranger. Due to this condition, some people force themselves to fight against the situation, while some other people feel stressed and tend to close themselves off from other people.

With the conditions as described, one of the things mentioned as a problem in the communication above is that this condition has also created a situation of disharmony in the communication process because cultural differences in communication styles can also cause problems such as misinterpretation, misinterpretation so that There are challenges that can hinder the process of communication between speakers and speakers, which is known as "disconnect" between speakers and speakers. In 
other words, there was a misunderstanding between encoding and decoding and significantly disrupted the ongoing communication process.

As described, the conditions have created a level of harmonization of dis-harmonious social relations between language users or communicators. Furthermore, because this study takes a sample or 'subject' of students as one of the social communities with its academic life characteristics, it is concluded that there has been a dis-harmonization of life among fellow students in campus life.

As explained in the research results section, several problem points need to be addressed in more detail in this section. These problems include the fact that Pattimura University students are really at a heterogeneous community level or heterogeneous community. The heterogeneity condition in the linguistic perspective in the regional language family category approach is found to be not very influential in a communication process that occurs directly from one another and in fact, it is found that there is a tendency for regional Malay language styles with varieties of characteristics that are superior to their influence in the communication process. . In other words, the approach to characterizing language is regional with characteristics (intonation, language style, slang/accent, frequency of speech, distortion, etc.) which play a more significant role in the communication process.

The following problems are related to the influence as intended above, from a scientific perspective in two different disciplines. One emphasizes the psychological aspects of striking inner pressure when communicating, fear with the inability to understand messages, fear of the term "disconnect" when speaking, etc. As narrated by Mulyana (2017), about fruit traders in Ambon greeting young people in Bandung, "Where are you going, Nyong?" The young man from Bandung was angry at being called "Nyong"; he thought he was called "Monyong," which means the mouth (dog or monkey) protrudes forward, whereas "Nyong" means the greeting for a young man, usually still a bachelor. " While others are more on the breaking of meaning, this is essential in the process of sending messages between decoding and encoding. Of course, even though the two problems are still in one perspective related to communication problems, it is necessary to look at it from a different perspective, from an ecological perspective, a cultural concept, and communication.

Problems in the communication process in terms of message acceptance are closely related to psychological issues such as experiences found as part of this study's results. This is none other than related to two critical issues, namely the condition of specific individuals and how the individual uses the language process verbally. This problem is closely related to what is emphasized by Tomasello (2008), "The human way of communicating - by deliberately reminding people of items for cooperative purposes - comes so easily to us that we can barely think of anything else. Tomasello added in the same section, in terms of unified communication then arose, cooperative communication is "the way to coordinate a collaborative activity of communication to be efficient, then building up the human psychological infrastructure of sharing intention (p. 8). Through this statement, it is undoubtedly clear that explicitly or implicitly, there is a close relationship between the individual psychological problems of language users on how to use language for communication purposes. More clearly related to the situation in question, Tomasello (2008) presents three options as a hypothesis related to the problem referred to as follows:

1. Human cooperative contact arose first in evolution (and happens first in ontogeny) in simple, accidental movements of pointing and pantomimizing.

2. Human cooperative cooperation is crucially dependent on the psychological infrastructure of mutual intentionality, which has developed to promote collaborative practices, and which requires, in particular: (a) social-cognitive abilities for developing shared intentions and mutual 
focus (and other types of common intellectual ground) for others; and (b) prosocial motives (and also norms) for supporting and communicating with others.

3. As expressed in one or the other human language, traditional communication is only effective when participants already have: (a) natural gestures and their mutual intentional infrastructure; and (b) cultural listening and imitation abilities for the development and dissemination of widely recognized communicative norms and constructions.

Communication apart from the psychological approach aspect, there is also an ecological approach (Soemarwoto, 2008) as a component in the human environmental management system that must also be reviewed together with other ingredients to get a balanced decision. The concept in ecology can be further refined if a more in-depth analysis can be made through interaction. On the other hand, Mulyana (2003) said that transactional communication is known in communication science, which is a process of meaning messages that are continuous, fluid, and communication actors are in an equal position. When humans communicate, then there is a process of interpreting messages that do not stand alone, meaning that the process occurs influenced by previous conditions. Meanwhile, from a cultural perspective, Sumarsono (2002) says that if ethnography is seen as a study of a society or ethnicity, then in ethnography, communication is focused on the community or community group's language. This is in line with Barbara Kapler Mikk (2011), with 5 (five) options for communication views from the cultural aspect, namely as follows:

1. Culture general teaching; students need to be embedded in the basic concept of culture to its essence in universal intercultural interaction.

2. Culture is specific; investing the community and including students with particular cultural competence into relevance.

3. Intercultural competence; providing opportunities to the community to acquire and improve their intercultural competencies.

4. Culture in the diversity; process to provide understandings of the community towards some potential cultural diversity in life.

5. Culture in skill approval; assisting the community in an autonomous life effectively, (on bkappler@umn.edu) accessible online.

In line with what was stated by Mikk (2011) above, Leech (1981) in Garde (2013) says that culture is "as the type of meaning which peace of language conveys about social circumstances of its use including the dimension of socio stylistic variants such as dialect, time, register, specialist language, (low, science, advertising, etc., genre, individualistic literary style and so on (Leech 1981).

\section{Conclusion}

This study shows that the Pattimura University students are not much different when compared to students at other large universities. The state of similarity or non-difference is meant to be related to the problem in a heterogeneity condition. Regarding the heterogeneity of these conditions, the Pattimura University students are generally categorized into several sections, as explained in the discussion.

Students have their characteristics and characteristics related to the condition of their approach to communication. In the communication activity or process, students are really in two situations that significantly affect their communication process. The two conditions referred to scientifically are in different areas; one is related to psychological problems, while the other is on practical issues, which are related to the communication process itself, especially issues that have become the fundamental essence in the communication process; it is related to the received messages or messages, especially things that are near related to meaning.

Referring to the factual conditions as intended, it is undoubtedly clear that the intra-andstudent communication process within Pattimura 
University's scope is still in the dis-harmonization category area. This condition has a powerful negative impact on life, especially on students' social life in the campus environment.

\section{References}

[1] Ahmed, M. (2013). Cross-Cultural Communication: Graduate School of International Relations. International University Jepang.

[2] Alwasilah. (2010). Language, Culture, and Education A Portrait of Contemporary Indonesia. Bandung: Andira.

[3] Axelson, R. D., \& Flick, A. (2010). Defining Student Engagement. Change: The Magazine of Higher Learning, 43(1), 38-43.

[4] Brown, L. (2009). A Failure of Communication On The Cross-Cultural Campus. Journal of Studies in International Education, 13(4), 439-454.

[5] Burlian, P. (2016). Patologi Sosial .Jakarta: Bumi Aksara

[6] Cahyono, E. (2014). Manajemen Kebencanaan Berbasis Mahasiswa. Jurnal Bisnis, Manajemen, dan Akuntansi, 2(2).

[7] Creswell, J. W. (2011). Educational Research Planning Conducting And Evaluating Quantitative and Qualitative Research 4th Edition. Library of Congres cataloging in Publication Data.

[8] DIS. (2016). Cross_Cultural Communication: Studi Abroad in Scandinavia.

[9] Emilia, E. (2008). Menulis Tesis dan Disertasi. Bandung: Alfabeta

[10] Garde, M. (2013). Culture, Interaction, and Person Reference in and Australia Language. Max Planck Institute for Psycholinguistics Nijmegen.

[11] González, K. P. (2002). Campus Culture And The Experiences Of Chicano Students In A Predominantly White University. Urban Education, 37(2), 193218.

[12] Ibrahim, A. S. (1994). Etnografi Komunikasi. Surabaya: Usaha Nasional.
[13] Istichomaharani, I. S., \& Habibah, S. S. (2016). Mewujudkan Peran Mahasiswa sebagai "Agent of Change, Social Control, dan Iron Stock". In Prosiding Seminar Nasional dan Call for Paper ke-2 "Pengintegrasian Nilai Karakter dalam Pembelajaran Kreatif di Era Masyarakat Ekonomi ASEAN.

[14] Kelly, E. (2015). Kecerdasan Interpersonal dan Kecerdasan Intrapersonal dengan Sikap Multikultural pada Mahasiswa Malang. Jurnal Psikologi: Jurnal Ilmiah Fakultas Psikologi Universitas Yudharta Pasuruan, 3(1), 39-59.

[15] Kudo, K., \& Simkin, K. A. (2003). Intercultural Friendship Formation: The Case of Japanese Students at An Australian University. Journal of intercultural studies, 24(2), 91-114.

[16] Kuswarno, E. (2009). Fenomenologi, Konsepsi, Pedoman dan Contoh Penelitian. Bandung: Widya Padjadjaran.

[17] Lee, C. (2004). Creating A Collaborative Campus Culture. Community College Journal of Research and Practice, 28(6), 503-511.

[18] Morey, A. I. (2000). Changing Higher Education Curricula for A Global and Multicultural World. Higher Education In Europe, 25(1), 25-39.

[19] Mulyana, D. (2003). Metodologi Penelitian Kualitatif: Paradigma Baru Ilmu Komunikasi dan Ilmu Sosial Lainnya. Bandung: Remaja Rosdakarya.

[20] Mulyana, D. (2017). Membongkar Budaya Komunikasi: Bandung: Remaja Rosdakarya.

[21] Munthe, A. G., \& Chandra, A. I. (2011). Profil Sikap terhadap Pluralisme: Perspektif Mahasiswa Atas Kehidupan Kampus dalam Konteks Nasional dan Global (Studi Kasus di UNPAR Bandung dan di UMM Malang). Research Report-Humanities and Social Science, 1.

[22] Permatasari, D., \& Bariyyah, K. (2016). Tingkat Kesadaran Multikultural Mahasiswa dan Urgensinya Bagi Bimbingan dan 
Konseling. JKI (Jurnal Konseling

Indonesia), 2(1), 22-28.

[23] Ralahalu, K. A. (2008). The Wonderful Island Maluku, Membangun kembali Maluku Dengan Nilai-nilai dan Khasanah Lokal, Serta Prinsip Entrepreneurial, Beragam Potensi dan Peluang Investasi, Jakarta: Gibon Group Publiccation.

[24] Rose-Redwood, C. R. (2010). The Challenge of Fostering Cross-Cultural Interactions: A Case Study of International Graduate Students'perceptions of Diversity Initiatives. College Student Journal, 44(2).

[25] Shen, X., \& Tian, X. (2012). Academic Culture and Campus Culture of Universities. Higher education studies, 2(2), 61-65.

[26] Soemarwoto, O. (2008). Ekologi, Lingkungan Hidup dan Pembangunan. Jakarta: Djambatan

[27] Sumarsono \& Paina, P. (2002). Sosiolinguistik. Yogyakarta: Pustaka Pelajar.

[28] Tomasello, M. (2008). Origins of Human Communication. Massachusetts Institute of Technology.

[29] Tonso, K. L. (2006). Student Engineers and Engineer Identity: Campus Engineer Identities As Figured World. Cultural Studies of Science Education, 1(2), 273-307.

[30] Turmudi, H. (2019). Participatory Communication Based on Digital Platforms for Communities in Indonesia. International Journal of Science and Society, 1(1), 70-80.

[31] Wild, L., \& Ebbers, L. (2002). Rethinking Student Retention in Community Colleges. Community College Journal of Research and Practice, 26(6), 503-519. 